\title{
SPANXN1 wt Allele
}

National Cancer Institute

\section{Source}

National Cancer Institute. SPANXN1 wt Allele. NCI Thesaurus. Code C92986.

Human SPANXN1 wild-type allele is located in the vicinity of Xq27 and is approximately 9 $\mathrm{kb}$ in length. This allele, which encodes sperm protein associated with the nucleus on the $\mathrm{X}$ chromosome $\mathrm{N} 1$ protein, may play a role in spermatid maturation. 